\title{
Retraction Note: Appraisal of Science and Economic Factors on Total Number of Granted Patents
}

\section{Dušan Marković ${ }^{1}$}

Published online: 12 November 2019

(C) Springer Science+Business Media, LLC, part of Springer Nature 2019

\section{Retraction Note to: Netw Spat Econ (2018) 18:1019-1026 https://doi.org/10.1007/s11067-017-9373-y}

The Editor-in-Chief has retracted this article (Marković 2018) because validity of the content of this article cannot be verified. This article showed evidence of authorship manipulation. The author does not agree to this retraction.

\section{Reference}

Marković D (2018) Netw Spat Econ. https://doi.org/10.1007/s11067-017-9373-y

Publisher's note Springer Nature remains neutral with regard to jurisdictional claims in published maps and institutional affiliations.

The online version of the original article can be found at https://doi.org/10.1007/s11067-017-9373-y

Dušan Marković

dusan.markovic@masfak.ni.ac.rs

1 Faculty of Mechanical Engineering, University of Nis, Nis 18000 , Serbia 